\title{
Enumeration of Total and Faecal Coliform Bacteria in Drinking Water of Khairpur City, Sindh, Pakistan
}

\author{
Abdul Hussain Shar, Yasmeen F Kazi, Miandad Zardari and Irshad Hussain Soomro \\ Department of Microbiology Shah Abdul Latif University, Khairpur, Sindh Pakistan
}

[Received 30 June 2007; Accepted 08 December 2007]

\begin{abstract}
Total coliform (TC) and faecal coliform (FC) bacteria were analyzed in drinking water of Khairpur city. Ninty samples were collected from main reservoir (source), distribution line and consumer taps. $\mathrm{pH}$ and residual chlorine of water samples were also determined. For bacteriological analysis inductively membrane filtration (MF) method was used for total coliform (TC) as well as faecal (FC) coliform bacteria. All samples were found contaminated with total coliform (TC) and faecal coliform (FC) and the counts were higher than the maximum microbial contaminant level (MMCL) established by World Health Organization (WHO). It was observed that $\mathrm{pH}$ was within the limits of WHO standard (6.5-8.5). The residual chlorine was not detected in any sample of drinking water. Bacteriologically the water quality of the drinking water is unsatisfactory.
\end{abstract}

Keywords: Coliform, Escherichia coli, Water quality, Contamination, Sanitation

Detection of microbial contaminants of faecal origin is a major priority in the control of drinking water quality. The presence of faecal contamination is most often evaluated using members of coliform group ${ }^{1}$. Waters from different sources, i.e., rivers, lakes, reservoirs and groundwater aquifers are subjected to varying degrees of faecal pollution, and consequently freshwater is a vector of transmission of many pathogenic bacteria, viruses and protozoa $^{2-4}$. Despite the world-wide efforts and modern technologies utilized for the production of safe water, the transmission of waterborne diseases is still a matter of major concern. For decades the faecal coliform groups of bacteria has been used as an indicator of water quality with respect to the presence of human pathogens, because rapid and reliable routine monitoring of the microbiological quality of water, therefore, will remain of fundamental importance in the control of waterborne diseases, and ideally the occurrence and levels of all human pathogens should be monitored ${ }^{5}$.

A great work has been done for the identification of contaminants of drinking water to prevent the water borne diseases throughout the world ${ }^{6-19}$. In Pakistan, the research work has been done on drinking water in different parts of country, but in interior part of Sindh province such work on drinking water quality has not been done so far. The Khairpur City was selected for present work in order to estimate the microbiological load, $\mathrm{pH}$ and chlorine disinfection of drinking water supplied to community. This city has the population of 1,20,000 and large number of people has been poured in city from rural areas. As the waterborne diseases are reported and people are unaware of problem of drinking water contamination, therefore this study is an attempt to asses the quality of drinking water at source point and change in quality during distribution. This investigation also involves forecasting of drinking water quality for people of area, the data would be a useful tool for creating awareness amongst the residents, planers and decision-makers for future water supply scheme.

Ninety samples in total, thirty samples from each site, i.e., main reservoir, distribution line and consumer taps, were collected. All sites were supplied from same water network that distributes water originating from surface water sources. Samples were collected in sterilized screw cap 500-ml white glass flasks (Pyrex), after a flow time of 5 min to eliminate any contaminant present. In order to neutralize the residual free chlorine, $10 \%$ solution sodium thiosulfate was added in sterile bottles ${ }^{17}$ after collection. Samples were placed in ice boxes and brought to laboratory. Water $\mathrm{pH}$ and residual chlorine were determined at the time of collection using pH PAL high accuracy electrochemistry test pen and residual chlorine was determined by employing HI 3831 free chlorine test kit. Microbiological samples were analyzed within $4 \mathrm{~h}$ of collection by membrane filtration method to determine the total coliform per $100 \mathrm{ml}$ at $37^{\circ} \mathrm{C}$ and faecal coliform at $44^{\circ} \mathrm{C}$ on eosine methylene blue (EMB) agar for $24 \mathrm{~h}$. Colonies were counted and all distinct colony types were transferred from EMB agar to trypticase soya agar (TSA) plates. Isolated colonies from TSA plates were subjected to Gram-staining and oxidase test. All the colonies tested were Gram-negative and oxidase negative rods.

The $\mathrm{pH}$ of all the 90 samples was found to be within the limits of WHO guidelines for drinking water ${ }^{20}$, i.e., $\mathrm{pH}$ 6.5-8.5 (Table 1). The residual chlorine was not detected in all samples colleted from different locations where as WHO has recommended the $0.2-0.5 \mathrm{mg} / \mathrm{l}$ for drinking water.

The results of the quantitative and qualitative bacteriological analyses the water samples collected from different site is summarized in Table 2. The total and faecal coliform bacteria were detected in all samples (100\%) of drinking water of Khairpur City

*Corresponding author:

Abdul Hussain Shar, Department of Microbiology Shah Abdul Latif University, Khairpur, Sindh Pakistan

Tel (Office): (0243) 9280286; E-mail: shar_strong@yahoo.com 
Table 1. pH and residual chlorine content of water samples collected from different sites

\begin{tabular}{lccccc}
\hline Site & $\begin{array}{c}\text { No. of } \\
\text { sample }\end{array}$ & Minimum & Maximum & Average & $\begin{array}{c}\text { WHO } \\
\text { limit }\end{array}$ \\
\hline pH & & & & & \\
$\quad$ Main reservoir & 30 & 6.31 & 7.41 & 7.37 & $6.5-8.5$ \\
$\quad$ Distribution line & 30 & 6.78 & 7.81 & 7.09 & $6.5-8.5$ \\
$\quad$ Consumer tap & 30 & 6.87 & 7.5 & 7.01 & $6.5-8.5$ \\
Residual chlorine (mg/l) & & & & & \\
$\quad$ Main reservoir & 30 & 0 & 0 & 0 & $0.2-0.5$ \\
$\quad$ Distribution line & 30 & 0 & 0 & 0 & $0.2-0.5$ \\
$\quad$ Consumer tap & 30 & 0 & 0 & 0 & $0.2-0.5$ \\
\hline
\end{tabular}

Table 2. Microbiological load in terms of total coliform and Escherichia coli in water samples collected from different sites

\begin{tabular}{|c|c|c|c|c|c|c|c|}
\hline \multirow[t]{2}{*}{ Site } & \multirow[t]{2}{*}{$\begin{array}{l}\text { No. of } \\
\text { sample }\end{array}$} & \multicolumn{3}{|c|}{$\begin{array}{c}\text { Total coliform } \\
\left(\log _{10} \text { cfu/100 ml) }\right.\end{array}$} & \multicolumn{3}{|c|}{$\begin{array}{c}\text { Faecal coliform } \\
\left(\log _{10} \mathrm{cfu} / 100 \mathrm{ml}\right)\end{array}$} \\
\hline & & Minimum & Maximum & Average & Minimum & Maximum & Average \\
\hline Main reservoir & 30 & 3.00 & 3.94 & 3.68 & 1.46 & 2.47 & 2.05 \\
\hline Distribution line & 30 & 3.79 & 4.39 & 4.06 & 2.00 & 3.26 & 3.00 \\
\hline Consumer tap & 30 & 4.00 & 4.30 & 4.15 & 2.50 & 3.53 & 2.99 \\
\hline
\end{tabular}

where the source was surface water. Total coliform counts ranged from $\log _{10} 3.0-3.94 \mathrm{cfu} / 100 \mathrm{ml}$, and faecal coliform (Escherichia coli) count ranged from $\log _{10} 1.46-2.47 \mathrm{cfu} / 100 \mathrm{ml}$.

High total and faecal coliform count in the consumers' tap and distribution line might be due contamination of water from the sewerage from where the damaged distribution line passes. Drinking water quality in both, urban and rural areas of Pakistan is not being managed properly. Results from various investigations provide evidence that most of the drinking water supplies are faecally contaminated ${ }^{21}$. Cryptosporidium was isolated in drinking water of some residential areas of Lahore ${ }^{22}$. Ihsanullah in $1999^{23}$ isolated E. coli in drinking water of Risalpur, Pubbi and Tarnab. The present study also supports the above reports in regards that the quality of drinking water in many parts of the Pakistan is not acceptable.

The detection of high counts of total coliform and faecal coliform (E. coli) implies a serious health concern. According to WHO guideline, drinking water should not total as well as faecal coliform bacteria. Therefore, it could be said that the bacteriological quality of drinking water of Khairpur City is unacceptable. The residual chlorine was not detected in any of drinking water samples that indicate lack of disinfection treatment of distribution system.

In conclusion, further work is needed to assess the quality of drinking water at every step of purification from the microbial point of view at all parts of Pakistan. In particular, samples taken prior to drinking water entering a distribution system should be regularly monitored to assess whether water is contaminated by biological and chemical agents or not before it is supplied to the consumers. The presence of any such contaminants in drinking water may pose serious health hazard.

\section{References}

1. Gleeson C \& Gary NF. 1997. The Coliform Index and Waterborne Disease: Problems of Microbial Drinking Water Assessment. E\&FN Spon Press, London.

2. Aneja KR. 1993. Experiment in Microbiology, Plant Pathology, Tissue Culture and Mushroom Cultivation, $2^{\text {nd }}$ edn, pp 288-301. Wishw Prakashana, New Age International (PVT) Ltd, New Delhi.

3. Blumenthal UJ, Peasey A, Ruiz-Palacios G \& Mara DD. 1999. Guidelines for Wastewater Reuse in Agriculture and Aquaculture: Recommended Revision Based on New Research Evidence. WELL Resource Centre/DFID (Study No 68, Part 1), London.

4. Feachman RG, Bradley DJ, Garelick H \& Dunean Mara D. 1983. Sanitation and Disease. Health Aspects of Excreta and Wastewater Management. John Willey \& Sons, New York.

5. Greenberg AE, Clesceri LS \& Eaton AD. 1998. Standard Methods for the Examination of Water and Wastewater, 20 ${ }^{\text {th }}$ edn. APHA, AWWA, WPCF and WEF. American Public Health Association (APHA), New York.

6. Kirschner AKT, Zechmeister TC, Kavka GG, Beiwl C, Herzig A, Mach RL \& Farnleitner AH. 2004. Integral strategy for evaluation of fecal indicator performance in bird-influenced saline inland water. $J$ Appl Environ Microbiol. 70: 7396-7403.

7. Araujo RM, Puig A, Lasobras J, Lucena F \& Jofre J. 1997. Phages of enteric bacteria in fresh water with different levels of faecal pollution. J Appl Microbiol. 82: 281-286.

8. Ejaz M \& Ahmed A. 2001. Physical, chemical and biological parameters in well waters of Karachi and their health impacts. J Chem Soc Pak. 23: 263-267.

9. $\mathrm{Yu} \mathrm{H}$ \& Bruno JG. 1996. Immunomagnetic-electrochemiluminescent detection of Escherchia coli 0157 and Salmonella typhimurium in foods and environmental water samples. J Appl Environ Microbiol. 62: $587-592$.

10. Lisle JT, Smith JJ, Edwards DD \& McFeters GA. 2004. Occurrence of microbial indicators and Clostridium perfringens in wastewater, water column samples, sediments, drinking water, and Weddell seal feces collected at McMurdo station Antarctica. J Appl Environ Microbiol. 70: 7269-7276. 
11. Alnoso JL, Soriano A, Carbajo O \& Amoros I. 1999. Comparison and recovery of Escherichia coli and thermotolerant coliforms in water with a chromogenic medium incubated at 41 and $44^{\circ} \mathrm{C}$. J Appl Environ Microbiol. 65: 3746-3749.

12. Kaltenthaler EC, Drasar BS \& Potter CW. 1996. The Use of Microbiology in Study of Hygiene Behaviour, Vol 88, pp 35-43. Faculty Press, Cambridge.

13. Anderson KL, Whitlock JE \& Harwood VJ. 2005. Persistence and differential survival of fecal indicator in subtropical waters and sediments. J Appl Environ Microbiol. 71: 3041-3048.

14. Kisteman T, ClaBen T, Koch C, Dangendorf F, Fischeder R, Gebel J, Vacata V \& Exner M. 2002. Microbial load of drinking water reservoir tributaries during extreme rainfall and runoff. J Appl Environ Microbiol. 68: 2188-2197.

15. Lee D-G \& Kim S-J. 2003. Bacterial species in biofilms cultivated from the end of the Seoul water distribution system. J Appl Microbiol. 95: 317-324.

16. Leoni E, De Luca G, Legnan PP, Sacchetti R, Stampi S \& Zanetti F. 2005. Legionella waterline colonization: Detection of Legionella species in domestic, hotel and hospital hot water systems. J Appl Microbiol. 98: 373-379.

17. Mellado V, Yanez MA, Catalan V. 2006. Evaluation of the microfoss system for the analysis of Escherichia coli in water. J Microbial Res. 161: $20-24$.

18. Roslev P, Bjergbaek LA \& Hesselsoe M. 2004. Effect of oxygen on survival of faecal pollution indicators in drinking water. J Appl Microbiol. 96: 938-945.

19. Thurman R, Faulkner B, Veal D, Cramer G \& Meiklejohn M. 1998. Water quality in Australia. J Appl Microbiol. 84: 627-632.

20. WHO. 1997. Guidelines for Drinking Water Quality, $2^{\text {nd }}$ edn, Vol 3. World Health Organization (WHO), Geneva.

21. Javed AA. 2003. Management of drinking water quality in Pakistan. J Eng Appl Sci. 22: 43-47.

22. Memon MH. 1997. Cryptosporidium: A water pathogen. Pak J Med Res. 36: 47-48.

23. Ihsanullah, Khan M, Khattak TN \& Sattar A. 1999. Determination of different contaminants in selective drinking water samples. The Nucleus. 36: 91-97. 